\title{
The Impact of Corporate Entrepreneurship on Firms' Financial Performance: Evidence from Istanbul Stock Exchange Firms
}

\author{
Korhan Karacaoglu ${ }^{1}$, Ali Bayrakdaroğlu² \& Firat Botan $\operatorname{San}^{2}$ \\ ${ }^{1}$ Department of Business Administration, Faculty of Economics and Administrative Sciences, Nevşehir \\ University, Turkey \\ ${ }^{2}$ Department of Business Administration, Faculty of Economics and Administrative Sciences, Muğla Sitkı \\ Koçman University, Kötekli, Muğla, Turkey \\ Correspondence: Ali Bayrakdaroğlu, Department of Business Administration, Faculty of Economics and \\ Administrative Sciences, Muğla Sıtkı Koçman University, Kötekli, Muğla, Turkey. E-mail: \\ ali.bayrakdaroglu@hotmail.com
}

Received: November 12, 2012

Accepted: December 4, 2012

Online Published: December 10, 2012

doi:10.5539/ibr.v6n1p163

URL: http://dx.doi.org/10.5539/ibr.v6n1p163

\begin{abstract}
In this study, it is aimed to show the interaction between financial performance and corporate entrepreneurship which can be identified as whole activities of new product, process, market, technology, strategy and improving management technique. In this respect, alternative two models to explain the interaction which is mentioned above were tested in an empirical research on 140 industrial manufacturing firms which are publicly trading in Istanbul Stock Exchange (ISE). Developed models and hypothesis are analysed by means of the Structural Equation Modelling (SEM) using LISREL. According to research findings it was determined that original dimensions of corporate entrepreneurship which is compound of innovation, risk taking and proactiveness has positive relation and interaction with financial performances of the firms. In addition; in the latest development in the related literature, autonomy and competitive aggressiveness variables which was added to the original dimension later on, did not show any relation with financial performances of firms.
\end{abstract}

Keywords: performance measures, Structural Equation Modelling, corporate entrepreneurship, Istanbul Stock Exchange

\section{Introduction}

Corporate entrepreneurship, which has become an important field of management study, was developed as a strategic orientation to overcome the external adaptation problems faced by firms which have been looking for sustainable competitive advantage in global competition in last thirty years. (Miller \& Friesen, 1978; Covin \& Slevin, 1989; Covin \& Covin, 1990). Corporate entrepreneurship which is also defined as entrepreneurial orientation and activities in an established organization is an important dimension of wealth creation and economic development. Researchers and practitioners have been interested in the concept since the early of 1980s because of its profitable effect on firms' performance (Zahra, 1991; Antoncic \& Hisrich, 2004).

The relationship between corporate entrepreneurship and wealth creation has not been adequately investigated in earlier studies. The majority of studies on corporate entrepreneurship (Zahra, 1991, 1993; Russell \& Russell, 1992; Zahra \& Covin, 1995; Antoncic \& Hisrich, 2004) examined direct effects of corporate entrepreneurship activities and orientation on both growth and profitability. While some of these studies concluded that corporate entrepreneurship has a strong impact on financial performance, some found out that there may not be such a strong interaction. Moreover, a great majority of these studies include strong and advanced economies. However, it is also determined that there are a few researches on developing countries and economies.

Based on the information given above, the purpose of this study is to investigate the effects of the dimensions such as corporate entrepreneurship; autonomy, risk taking, innovation, proactiveness and competitive aggressiveness on Turkish firm's financial performance as one of the emerging market.

In this context, firstly the concept of corporate entrepreneurship will be described. Secondly, five-dimensions of this term will be explained in the historical background. Then there will be a part related to the impact of corporate entrepreneurship on firms' performance. Finally, in the last part the empirical research and its results 
will be evaluated to measure the effects of cooperate entrepreneurship on financial performances of firms in ISE.

\section{Theoretical Framework}

\subsection{Corporate Entrepreneurship}

Corporate entrepreneurship is described as entrepreneurship within an organization which refers to emergent behavioral intentions and organizational behaviors that lead a deviation from the traditional forms of doing business. (Antoncic \& Hisrich, 2004). Corporate entrepreneurship processes take place within an existing organization without thinking of the its size, and these processes do not only refer to creation of new business ventures but also to development of new products, services, technologies, managerial techniques, strategies and also competitive standing as innovative activities. Qualifications of corporate entrepreneurship comprise new business venturing, innovation of product/service and innovation of process, self-renewal, risk taking, proactiveness and competitive aggressiveness. Concepts such as intrapreneuring, intrapreneurship, intra-corporate entrepreneurship, corporate venturing, internal corporate entrepreneurship, innovative and entrepreneurial strategy making, firm level entrepreneurial standing and entrepreneurial orientation have also been used to define the phenomenon of corporate entrepreneurship (Antoncic \& Hisrich, 2004).

Corporate entrepreneurship stands for a new management philosophy which promotes strategic agility, flexibility, continuous creativity to change administrative-oriented employees into intrapreneurs (Kraus \& Kauranen, 2009). Corporate entrepreneurship, one of the important sub-fields of entrepreneurship, can also be described as "the processes whereby an individual or a group of individuals, in association with an existing organization, create a new organization or instigate renewal or innovation within that organization" (Sharma \& Chrisman, 1999).

\subsection{Dimensions of Corporate Entrepreneurship}

As in the other studies in the literature, corporate entrepreneurship, in this study, is analyzed within threedimensions such as innovation, risk taking and proactiveness. Additionally, instead of organizational renewal, competitive aggression dimension and autonomy which have increasingly become popular in recent years are also taken into consideration.

Innovation, risk-taking and proactiveness defined by Miller (1983) and developed by Covin and Slevin (1986, 1989) are "original dimensions" of corporate entrepreneurship. The innovativeness dimension of corporate entrepreneurship deals with new ideas, experiences, originality and creative processes which are separate issues from current practice and trends related to technologies (Lumpkin \& Dess, 1996; Wiklund \& Shepherd, 2005). The innovativeness indicates an organizational tendency to offer newness and originality via experimentation and research at new products, services and new processes development. (Dess \& Lumpkin, 2005; Lumpkin \& Dess, 2001).

Risk taking is related to the willingness to transfer of more resources to projects where can be high cost of failure (Miller \& Friesen, 1978). It can also be referred as transferring resources to projects where the results are unknown. Moreover, the dimension of risk taking widely reflects the desire of company to refrain from the tried-and-true and to venture into the unknown. (Wiklund \& Shepherd, 2005). Corporate risk taking can be conceptualized as the organizational attitude to apply new venture for the aim of corporate profitability and growth by tolerating the estimated probable losses (Bulut \& Yilmaz, 2008). Risk-taking indicates a tendency to take courageous actions such as embarking on a new enterprise, transferring a great deal of resources to ventures with indefinite outcomes and/or obtaining heavily (Lumpkin \& Dess, 2001).

Proactiveness means a position of predicting and acting on future desires and demands in the marketplace, thereby forming a first-mover advantage against competitors (Lumpkin \& Dess, 1996). From such a future-oriented perspective, proactive firms want to be leaders by capitalizing on generated opportunities (Wiklund \& Shepherd, 2005). Additionally, proactiveness also refers to the satisfying the market opportunities by being the first mover into the market (Bulut \& Yllmaz, 2008). In a different definition, proactiveness is a search for opportunity, future perspective including presenting new products or services ahead of the competition and acting with the thought of future need to create alteration and shape the environment (Lumpkin \& Dess, 2001).

Although Miller (1983) defined the corporate entrepreneurship separately as innovation, risk taking and proactiveness, some researchers tested and developed competitive aggressiveness which is the fourth dimension of entrepreneurial orientation (Covin \& Covin, 1990).

Competitive aggressiveness demonstrates the intensity level of firms' attempts to outperform industry competitors identified by a combative stance and a strong response to rival's actions (Lumpkin \& Dess, 2001). 
Even though various studies on corporate entrepreneurship, for example, Smart and Conant (1994) have neglected the competitive aggressiveness dimension, the emphasis was made primarily on this aspect of corporate entrepreneurship by other researchers. In some studies, the concepts of competitive aggressiveness and proactiveness have been treated as if they are identical with each other (Covin \& Covin, 1990). In contrast, Lumpkin and Dess (1996) have suggested that these two are different dimensions (Lumpkin \& Dess, 2001). Competitive aggressiveness and agility cover the entrepreneurial orientation and activities of top management (Antoncic \& Hisrich, 2004).

Autonomy is explained as an individualistic or team action intending producing a business conception or perception and carrying it through to conclusion (Lumpkin \& Dess, 2001). Autonomy provides the flexibility and freedom to the members of the organization to portray and develop the entrepreneurial initiatives (Lumpkin et al., 2009). Although autonomy was suggested as a dimension of corporate entrepreneurship by Dess \& Lumpkin, few studies have analyzed it as an independent dimension (Lumpkin \& Dess, 2001). It is believed that there are two reasons for this lack.

As a first, autonomy is not one of the original dimensions of corporate entrepreneurship classified by Miller (1983) and developed by Covin and Slevin $(1986,1989)$ such as innovativeness, proactiveness and risk taking. Moreover, some researchers have claimed that autonomy is a reason for initiative behavior rather than necessary parts of it. As a second, the acceptance of the autonomy dimension has been obstructed by the absence of a valid firm-level scale that measures autonomy from the perspective of corporate entrepreneurship. A variety of administrative autonomy scales were used in previous researches, however it is found that only a few of them are suitable for evaluating corporate entrepreneurship-related autonomy (Lumpkin et al., 2009). Autonomy, in the context of corporate entrepreneurship or entrepreneurial orientation, is necessary to increase the existing strength above the current capabilities of organizations, and it is also important to promote the development of advanced business practices or new initiatives. In fact, some researchers discuss that autonomy is required to reveal the entrepreneurial initiative as a feature based on the organization's entrepreneurial orientation (Antoncic \& Hisrich, 2004; Lumpkin et al., 2009).

\subsection{Relationship between Corporate Entrepreneurship and Firm's Performance}

The studies on Corporate Entrepreneurship in developed economies especially after 1990's have revealed that entrepreneurial activities within the firms provide successful firm performances (Pinchot, 1985; Zahra \& Covin, 1995; Barringer \& Bluedorn, 1999; Lumpkin \& Dess, 2001; Simsek et al., 2009; Phillip et al., 2009; Rajshekkar, et al., 2012). Most of these studies show that the corporate entrepreneurship has a multi-dimensional structure. The most common determined and checked hypotheses dimensions of Corporate Entrepreneurship are risk taking, innovation, proactiveness and competitive aggressiveness (Sharma \& Chrisman, 1999; Dess et al., 2003). However, these relationships have not proven corporate performance yet (Zahra, 1991; Antoncic \& Hisrich, 2004; Dess \& Lumpkin, 2005).

Several studies investigating the relationship between corporate entrepreneurship and firm performance concluded that corporate entrepreneurship has led to the development of the company performance (Naman \& Slevin, 1993; Zahra, 1991, 1993; Zahra \& Covin, 1995; Kaya, 2006). Most of the studies on Corporate Entrepreneurship (Zahra, 1991, 1993; Russell \& Russell, 1992; Zahra \& Covin, 1995) examined the direct impact of orientation and activities of Corporate Entrepreneurship on both growth and profitability (Antoncic \& Hisrich, 2004). In the majority of these studies suggest that Corporate Entrepreneurship increases the profitability and growth which have positive effect on increasing the performance of firms. Especially Corporate Entrepreneurship is a remarkable aspect of profitable and growing companies. Therefore, it is considered that businesses giving more importance to the corporate entrepreneurship practices display higher level of performance rather than other firms. The theoretical basis for the relationship or interaction between corporate entrepreneurship and firm performance is based on resource-based perspective, since the resource-based perspective indicates the importance of firms' specific resources and capabilities for acquiring sustainable competitive advantage over their competitors (Danışman \& Erkocaoğlan, 2007). As a result, in the organization, innovation, risk taking, proactiveness, competitive aggressiveness and autonomous behaviors of corporate entrepreneurship, are assessed and used as a tool for getting competitive advantage and it is specific for the firm and cannot be imitated. There are numerous studies done on the relationship between corporate entrepreneurship and firm performance, especially in developed countries (Lumpkin \& Dess, 1996; Wiklund, 1999; Zahra \& Covin, 1995). These studies showed strong relationship between the two concepts, on the other hand there are limited numbers of research in less developed or developing economies. For example, study was made by comparison of Slovenia and America in terms of profitability and growth criteria under the impact of corporate entrepreneurship on firm performance by Antoncic and Hisrich (2001), and different results were obtained at the 
end of this study.

According to a limited number of studies on interaction between corporate entrepreneurship and firm's financial performance that conducted in Turkey as a developing market, there are different relationship and interaction between concepts in terms of these five different dimensions. The results of research that conducted by Danışman and Erkocaoğlan (2007) on companies that publicly traded on Istanbul Stock Exchange (ISE) showed that there is a positive relationship between corporate entrepreneurship dimension of innovation and firms' profitability and there is no significant relationship with growth. In another study that conducted by Aktan and Bulut (2008) demonstrated that, corporate entrepreneurship dimensions of risk taking, competitive aggressiveness, innovation and proactiveness have a weak impact on firms' financial performance. Another study that made by Kaya (2006) concluded that there is moderate and positive relationship between corporate entrepreneurship and firms' performance, and human resources was taken as an intermediary between those two concepts. According to research on 347 companies made by Fiş and Çetindamar (2009), there is a strong relationship between corporate entrepreneurship and firm's financial performance. In the studies above, the corporate entrepreneurship dimensions were examined, results has been concluded that one or several of these dimensions have effect on business performance. In this study, a combination of all these dimensions are expected to be effective on the performance of firm and predicted that statistical analysis and models used in research will reveal this.

\section{An Empirical Study on Firms Operating in Istanbul Stock Exchange (ISE)}

\subsection{Purpose and Importance of the Study}

In this study, it was tried to determine how and in which direction corporate entrepreneurship affects the business performance. The impact of corporate entrepreneurship on firm's financial performance was revealed by testing the two developed model via structural equation models. The research was carried out by 140 institutionalized manufacturing firms that operate in Istanbul Stock Exchange (ISE) in Turkey as a developing market and it was tried to determine how corporate entrepreneurship affects firms' performance. The data was obtained through a private research company. And also, corporate entrepreneurship scale with a total of 16 items was adapted to Turkish. There are similar studies about impact of corporate entrepreneurship on firms' performance in Turkish literature (Danışman \& Erkocaoğlan, 2007; Aktan \& Bulut, 2008; Altuntaş \& Dönmez, 2010). However, this research indicates differences from some aspects of the mentioned studies in terms of scope and method.

As the scope of this research, corporate entrepreneurship is considered under similar titles as other studies of the literature such as, innovation, risk taking, proactiveness. However, dimension of competitive aggressiveness instead of organizational renewal, and autonomy dimension which is analyzed more in recent studies are considered as two separate dimensions in this study. Although the literature indicates that firm performances are viewed in the context of subjective (perceptual) measures (Altuntaş \& Donmez, 2010) or with the criteria of profitability and sales growth (Danısman \& Erkocaoğlan, 2007), in this study, more quantitative performance criteria, such as return on assets (ROA), return on equity (ROE), net profit margin (NMP), earnings before interest, tax, depreciation and amortization/ sales (EBITDA/S), earnings before interest tax/assets (EBIT/A) and net sales revenue/assets are taken into consideration, and hence the operating performance is also examined perceptually, but in a broader context. Additionally, previous surveys to measure firm's financial performance encompasses last three-year period, but this study encompasses last five-year period of firm performance. Although the interaction between corporate entrepreneurship and firm performance had been analyzed with regression and correlation analyses in previous studies, the relationship between the concepts were tested with structural equation modeling in this study.

\subsection{Method}

\subsubsection{Sampling and Data Mining Method}

Research was carried out with 140 firms that operate in manufacturing industry and publicly traded on the ISE. By 2012, the number of firms in the manufacturing industry registered to ISE is a total of 175. In the study, random sampling method was used, and it was reached to $80 \%$ of the main population. Survey method was used in order to collect the data in this study. The data collected from the ISE listed companies through a private research company. For the measurement of corporate entrepreneurship five point Likert scale with 16 items was used. Covin and Slevin (1986)s' scale was used for nine items related to innovation, proactiveness and risk-taking dimensions, Dess and Lumpkin (2005)s' scale was used for three items related to competitive aggressiveness dimension and Lumpkin et al. (2009)s' scale was used for four items related to autonomy dimension. 
Six different quantitative performance data related to profitability and sales figures in the last five years were used in order to measure firm's financial performance. The scale developed for this study to measure firms' financial performance is the most widely used one in the literature as being efficiency, growth, profitability and sales criteria. Five item semantic differential scale was used for these criteria in this study, which was developed in 1957 by Osgood et al. According to this, each criteria are described as 'below the industry average' on one side of the scale and above the industry average' on the other side of the scale. According to semantic differential test of Osgood et al. (1957), the scale referred to two opposite sides and asked responder to mark the appropriate number. Considering the difficulties about the definition of performance in the field of entrepreneurship, it is felt that there is a lack of a guide for performance appraisal (Brush \& Vanderwerf, 1992; Haber \& Reichel, 2005). According to Murphy et al. (1996), and Foxal and Greenleys' (1998) views about the quantitative performance criteria, a perceptual scale which is related to efficiency, growth, profitability and size / liquidity was used.

In the questionnaire, the managers of enterprises were asked to choose the best option according to their financial performance situation related to six criteria on the five-point semantic differential scale. Since each performance criteria independently are meaningful, validity and reliability analyses have not been carried out for any statements regarding to financial performance.

\subsubsection{Theoretical Model and Hypotheses}

Figure 1 describes the variables in the research model; corporate entrepreneurship is composed of elements of autonomy, innovation, risk taking, proactiveness and competitive aggressiveness. According to this, corporate entrepreneurship, which is the first variable of the research, is referred as independent variable and financial performance that consists of quantitative financial data of the business enterprises which is a latent variable is referred as dependent variable. In the related field of literature; Rauch et al. (2004), Yang et al. (2007), Fis and Cetindamar (2009) examined the corporate entrepreneurship as a structure with five dimensions as well as in this study.

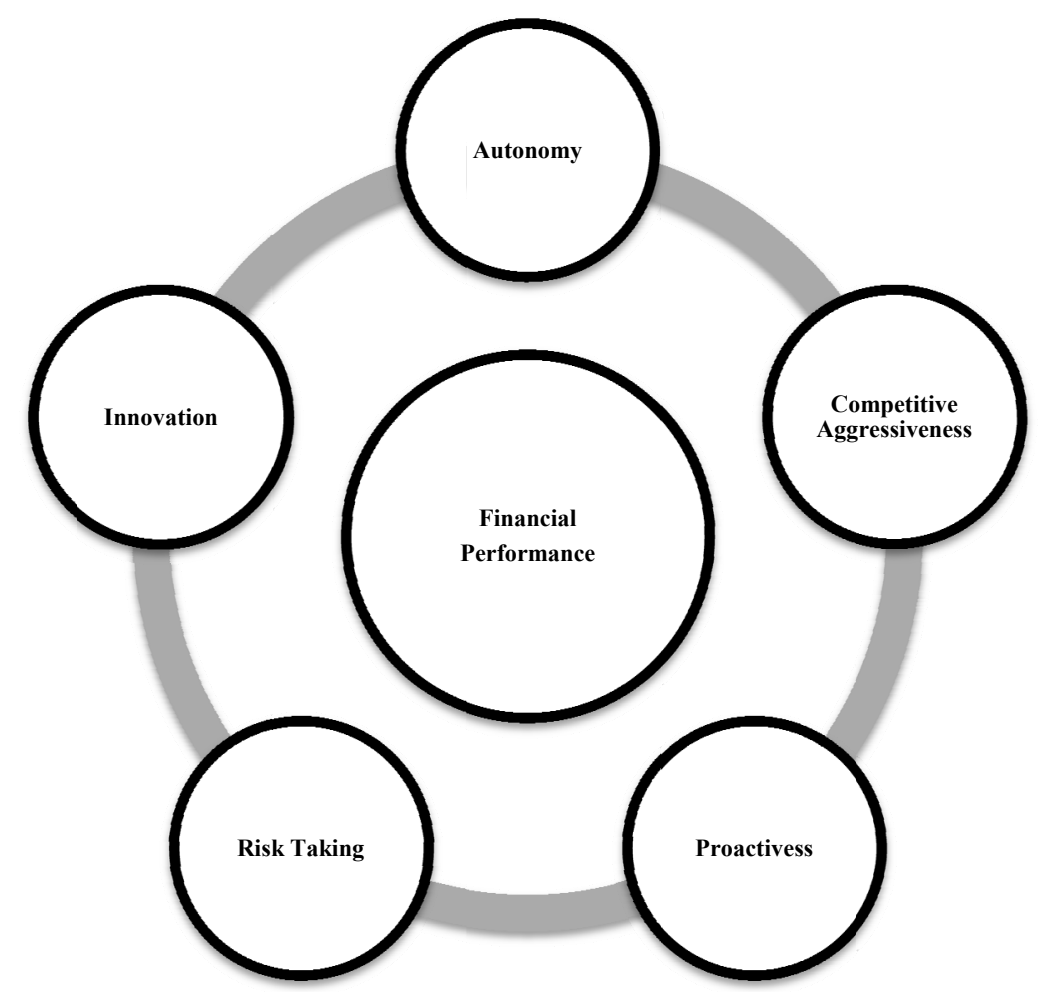

Figure 1. Theoretical Model for Relation of Corporate Entrepreneurship and Firms' Performance

Alternative hypotheses for five dimensions of corporate entrepreneurships' impact on firms' financial performance are shown below:

$\mathbf{H}_{\mathbf{1}}$ : Autonomy as a dimension of corporate entrepreneurship, affects firms' performance.

$\mathbf{H}_{2}$ : Innovation as a dimension of corporate entrepreneurship, affects firms' performance.

$\mathbf{H}_{3}$ : Risk taking as a dimension of corporate entrepreneurship, affects firms' performance. 
$\mathbf{H}_{4}$ : Proactiveness as a dimension of corporate entrepreneurship, affects firms' performance.

$\mathbf{H}_{5}$ : Competitive aggressiveness as a dimension of corporate entrepreneurship, affects firms' performance.

\section{Data Analysis}

The data obtained were analyzed using statistical packages SPSS and LISREL. In this context, exploratory and confirmatory factor analysis was used for the reliability and validity, and for presenting the factor structure of the scale of corporate entrepreneurship. Resolution of path analysis (which was made under structural equation model of alternative models) was utilized to reveal the causal relationship between corporate entrepreneurship and performance variables. Structural Equation Model (SEM) is a comprehensive statistical technique used to test the causal relationships between observed and latent variables (Y1lmaz, 2004). SEM is a method that consists of a mixture of confirmatory factor analysis and multiple regression techniques and helps to evaluate the newly developed model. SEM is a more complicated analytical model of regression and analytical factor models which measure various relationship sets simultaneously (Brewerton \& Millward, 2001; Hair et al., 2006).

In this research, validity of corporate entrepreneurships' scale was discussed in the context of construct validity concept. For construct validity of the scale, primarily exploratory factor analysis, then confirmatory factor analysis was conducted. In the literature, it is agreed that factor analysis is the most common statistical method to put forth the construct validity. Both exploratory factor analysis and confirmatory factor analysis have been used together in many of scale adaptation and validation studies. It is preferred to use exploratory factor analysis first, then confirmatory analysis (Jöreskog \& Sörbom, 1993). Exploratory factor analysis is beyond the reduction of the variable and naming the results of analysis. It also reveals if there are similarities between outcome factors of the analysis and theory of structure that helps to understanding of behavior. In other words, an inquiry is made, whether the indicators that collected under a certain factor are the indicators of theoretical structure or not. In the confirmatory factor analysis, whether the structure was verified or not was tested based on the data which was obtained through measurement tool that was developed in line with a theoretical structure. This extremely powerful technique is commonly used to determine the validity of the structure and thus to develop a theory and to test the validity of the existing theories.

To determine the factor structure of corporate entrepreneurship scale, exploratory factor analysis was conducted. Desired values of variables under each factor is 0.50 and above (Nunnally, 1978). In Table 1, sum of factor values that collected under each five dimensions is varied in the range of 0.64 to 0.92 and above the 0.50 threshold that provides the desired condition.

KMO coefficient which represents the appropriateness of the sample to the factor analysis is 0.85 . So, data structure is suitable for factor analysis. It is seen that the chi-square value obtained from Bartlett test is meaningful at the level of 0.01 . This result means that the data comes from a multivariate normal distribution; therefore it proves another assumption of factor analysis.

In Table 1, it is observed that the scale which was used is in theoretically expected form and has five factors of which Eigen values are bigger than 1 as a result of factor analysis which is done as a result of the principal components method and Varimax Rotation. Factor names; autonomy, competitive aggressiveness, innovation, risk taking and proactiveness occurred as it is in the original form. Because factor values of all variables are greater than 0.50 , none of the items were out of analysis. Five factors with eigenvalues greater than one explain $73.43 \%$ of the total variance and this is above the acceptance rate which is $60 \%$; autonomy explains the total variance at the rate of $21.45 \%$, competitive aggressiveness explains at the rate of $14.63 \%$, innovation explains at the rate of $14.22 \%$, risk taking dimension explains at the rate of $11.89 \%$ and proactiveness dimension explains at the rate of $11.23 \%$. As a result, dimensions in this study match one to one with dimensions in scales' original form.

Confirmatory factor analysis was applied to test the consistence of the obtained data with determined factor structure of corporate entrepreneurships' scale (Simsek, 2009). Second-level confirmatory factor analysis, which is a step in the analysis of structural equation models, was used to test the validity of the scale. In other words, confirmatory factor analysis was used in order to verify, whether corporate entrepreneurship scale overlaps with a five-dimensional structure in exploratory factor analysis or not. Therefore, it has been applied to determine the structure validity. 
Table 1. Factor Analysis of Corporate Entrepreneurship Scale

\begin{tabular}{|c|c|c|c|}
\hline Factor/Variable & $\begin{array}{l}\text { Factor } \\
\text { Loadings }\end{array}$ & $\begin{array}{l}\text { Variance } \\
\text { Explained }\end{array}$ & Alpha \\
\hline \multicolumn{4}{|l|}{ Factor 1: Autonomy } \\
\hline $\begin{array}{l}\text { A3. In my firm, individuals and/or teams pursuing business opportunities make decisions on their } \\
\text { own without constantly referring to their supervisors (instead of having to obtain approval from their } \\
\text { supervisors before making decisions). }\end{array}$ & 0.920 & 21.45 & 0.93 \\
\hline $\begin{array}{l}\text { A1. My firm supports the efforts of individuals and/or teams that work autonomously as compared } \\
\text { with requiring individuals and/or teams to rely on senior managers to guide their work. }\end{array}$ & 0.895 & & \\
\hline $\begin{array}{l}\text { A2. The managers of my firm believe that the best results occur when individuals and/or teams decide } \\
\text { for themselves what business opportunities to pursue (rather than when the CEO and top managers } \\
\text { provide the primary impetus for pursuing business opportunities). (R) }\end{array}$ & 0.883 & & \\
\hline $\begin{array}{l}\text { A4. In my firm, the CEO and top management team (rather than employee initiatives and input) play } \\
\text { a major role in identifying and selecting the entrepreneurial opportunities my firm pursues (R) }\end{array}$ & 0.843 & & \\
\hline \multicolumn{4}{|l|}{ Factor 2: Competitive Aggressiveness } \\
\hline $\begin{array}{l}\text { CA3. My firm knows when it is in danger of acting overly aggressive and avoid such actions which } \\
\text { can lead to erosion of firm reputation and retaliation by competitors }\end{array}$ & 0.889 & 14.63 & 0.78 \\
\hline $\begin{array}{l}\text { CA1. My firm effectively uses an aggressive posture to combat industry trends that may threaten our } \\
\text { survival or competitive position }\end{array}$ & 0.823 & & \\
\hline $\begin{array}{l}\text { CA2. My firm enhances its competitive position by entering markets with drastically lower prices, } \\
\text { copying the business practices or techniques of successful competitors, or making timely } \\
\text { announcements of new products or technologies. }\end{array}$ & 0.692 & & \\
\hline \multicolumn{4}{|l|}{ Factor 3: Innovativeness } \\
\hline $\begin{array}{l}\text { I2. In the last five years, my firm has marketed no new lines of products or services as compared with } \\
\text { very many new product lines or services. (R) }\end{array}$ & 0.886 & 14.22 & 0.82 \\
\hline $\begin{array}{l}\text { I3. In my firm, changes in product or service lines have been mostly of a minor nature as compared } \\
\text { with being quite dramatic (R) }\end{array}$ & 0.863 & & \\
\hline $\begin{array}{l}\text { I1. In general, top managers of my firm favor a strong emphasis on the marketing of tried and true } \\
\text { products and services as compared with an emphasis on } \mathrm{R} \& \mathrm{D} \text {, technological leadership, and } \\
\text { innovations. }\end{array}$ & 0.811 & & \\
\hline \multicolumn{4}{|l|}{ Factor 4: Risk Taking (Riskiness) } \\
\hline $\begin{array}{l}\text { R2. The top managers of my firm believe that, owing to the nature of the environment, it is best to } \\
\text { explore the environment gradually via careful, incremental behavior (rather than bold, wide-ranging } \\
\text { acts necessary to achieve the firm's objectives) (R) }\end{array}$ & 0.843 & 11.89 & 0.72 \\
\hline $\begin{array}{l}\text { R3. When confronted with decision-making situations involving uncertainty, my firm typically adopts } \\
\text { a cautious, "wait-and-see" posture in order to minimize the probability of making costly decisions (as } \\
\text { compared with a bold, aggressive posture to maximize the probability of exploiting potential } \\
\text { opportunities) (R) }\end{array}$ & 0.791 & & \\
\hline $\begin{array}{l}\text { R1. The top managers of my firm have a strong proclivity for low risk projects (with normal and } \\
\text { certain rates of return) rather than high risk projects (with chances of very high return) (R) }\end{array}$ & 0.635 & & \\
\hline \multicolumn{4}{|l|}{ Factor 5: Proactiveness } \\
\hline $\begin{array}{l}\text { P3. In general, the top managers of my firm have a strong tendency to be ahead of other competitors } \\
\text { in introducing novel ideas or products }\end{array}$ & 0.759 & $\mathbf{1 1 . 2 3}$ & 0.70 \\
\hline $\begin{array}{l}\text { P2. In dealing with competition, my firm is very seldom the first business to introduce new } \\
\text { products/services, administrative techniques and operating technologies }(\mathrm{R})\end{array}$ & 0.752 & & \\
\hline $\begin{array}{l}\text { P1. In dealing with competition, my firm typically responds to action which competitors initiate as } \\
\text { compared with initiating action which the competition then responds to.(R) }\end{array}$ & 0.660 & & \\
\hline Kaiser-Meyer-Olkin - KMO 0.85 Total Variance Explained \% 73.43 & & & \\
\hline
\end{tabular}

Note: (R) Reverse coded.

Figure 2 shows factor loads of variables and the path diagram which includes the results of confirmatory factor analysis of the scale. Evaluation of the results of confirmatory factor analysis showed that five-dimensional structure is maintained. The dimensions that have the most powerful relationships with corporate entrepreneurship latent variable are; proactiveness (0.97), innovation (0.89), autonomy (0.78), risk taking (0.44) and lastly competitive aggressiveness (0.71). 


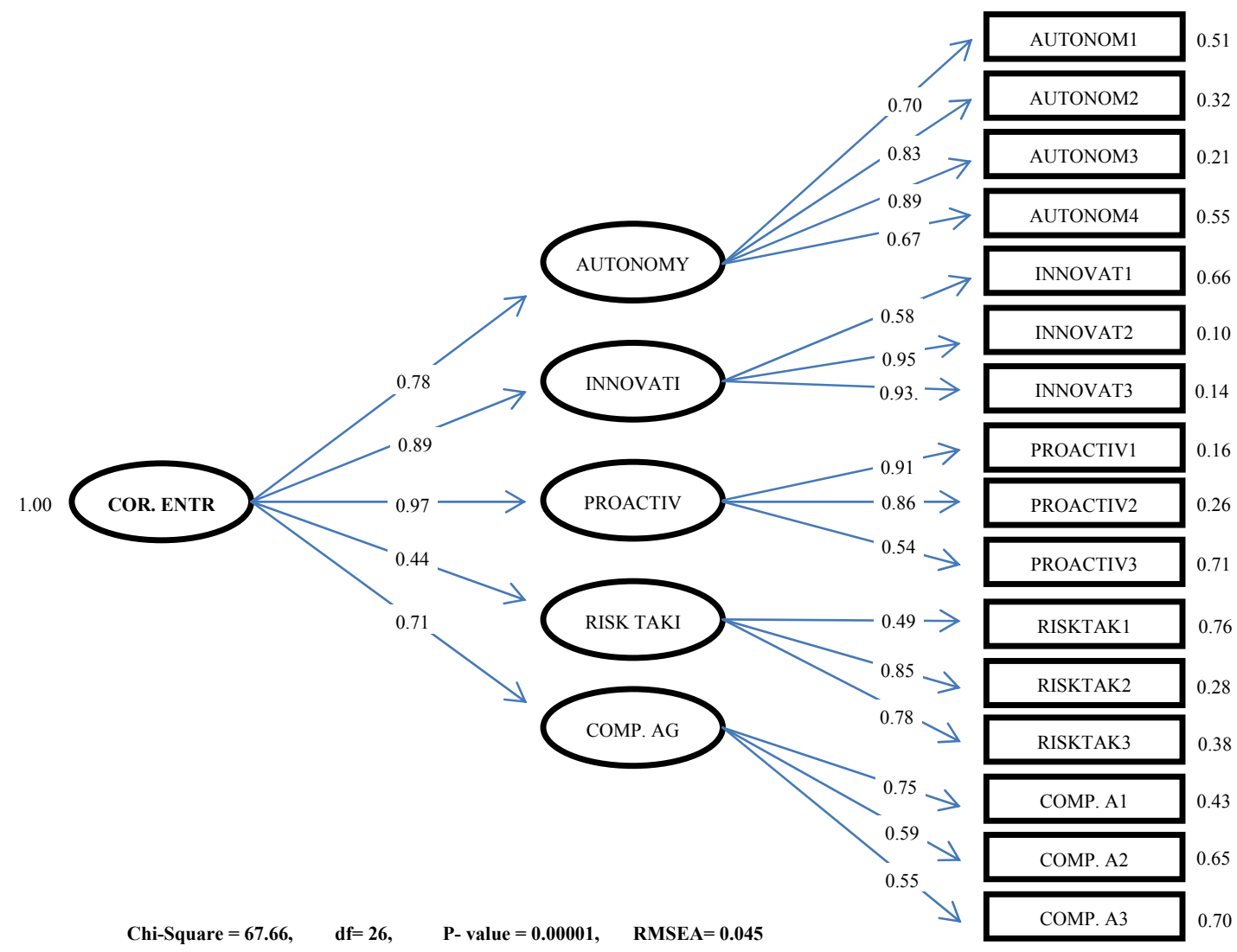

Figure 2. The results of Confirmatory Factor Analysis of Corporate Entrepreneurship Scale

In order to assess the research model as a whole, the values of goodness of fit statistics are taken into account. Goodness of fit statistics can be interpreted by using some acceptable limit values for the acceptance of the model. One of the most commonly used goodness of fit value is $\mathrm{X}^{2}$ (chi-square). This value is required to be meaningless. As can be seen in Table-2; if X2/df (degrees of freedom) value is less than two, it means that it is a good model. If the value is five or less than five, it means that it has an acceptable goodness of fit value. Apart from $\mathrm{X}^{2}$, most commonly used and recommended indexes are GFI (Goodness of Fit Index), AGFI (Adjusted Goodness of Fit Index) and RMSEA (Root-Mean-Square Error Approximation) (Jöreskog \& Sörbom, 1993). Other goodness of fit measures are CFI (Comparative Fit Index) and NFI (The Normed Fit Index).

Table 2. Confirmatory Factor Analysis of Corporate Entrepreneurship Scale (Goodness of Fit Statistics)

\begin{tabular}{llll}
\hline Goodness of Fit Index & Good Value & Acceptable Value & Measurement Model Value \\
\hline $\mathrm{X}^{2} / \mathrm{df}$ & $\mathrm{X}^{2} / \mathrm{df}<2$ & $\mathrm{X}^{2} / \mathrm{df}<5$ & $\mathrm{X}^{2} / \mathrm{df}=67.66 / 26=\mathbf{2 . 6}$ \\
$\mathrm{GFI}$ & $0.95<\mathrm{GFI}<1$ & $0.90<\mathrm{GFI}<0.95$ & $\mathrm{GFI}=\mathbf{0 . 9 0}$ \\
$\mathrm{AGFI}$ & $0.95<\mathrm{AGFI}<1$ & $0.90<\mathrm{AGFI}<0.95$ & $\mathrm{AGFI}=\mathbf{0 . 9 1}$ \\
$\mathrm{CFI}$ & $0.95<\mathrm{CFI}<1$ & $0.90<\mathrm{CFI}<0.95$ & $\mathrm{CFI}=\mathbf{0 . 9 4}$ \\
$\mathrm{RMSEA}$ & $0<\mathrm{RMSEA}<0.05$ & $0.05<\mathrm{RMSEA}<0.08$ & $\mathrm{RMSEA}=\mathbf{0 . 0 4 5}$ \\
$\mathrm{NFI}$ & $0.95<\mathrm{NFI}<1$ & $0.90<\mathrm{NFI}<0.95$ & $\mathrm{NFI}=\mathbf{0 . 9 6}$ \\
\hline
\end{tabular}

Table 2 concludes that, according to the results of confirmatory factor analysis of corporate entrepreneurship scale, goodness of fit statistics are good and at acceptable range and $t$ values are meaningful.

\section{Findings}

Research consists of testing two alternative models of corporate entrepreneurship within the scope of structural equation model; one is the last point reached in the literature with a total of five-dimensions and the other deals with the concept in its originally developed form and has a total of three-dimensions. Initially, first model which had been developed in order to reveal the impact of a total of five dimensions of corporate entrepreneurship on firms' financial performance was put into structural equation modeling. In this way, five hypotheses of this 
research and corporate entrepreneurship scale with five dimensions were tested. LISREL 8.54 program was used for calculating the covariance matrices of the models. The results obtained after testing the model are shown in Figure 3.

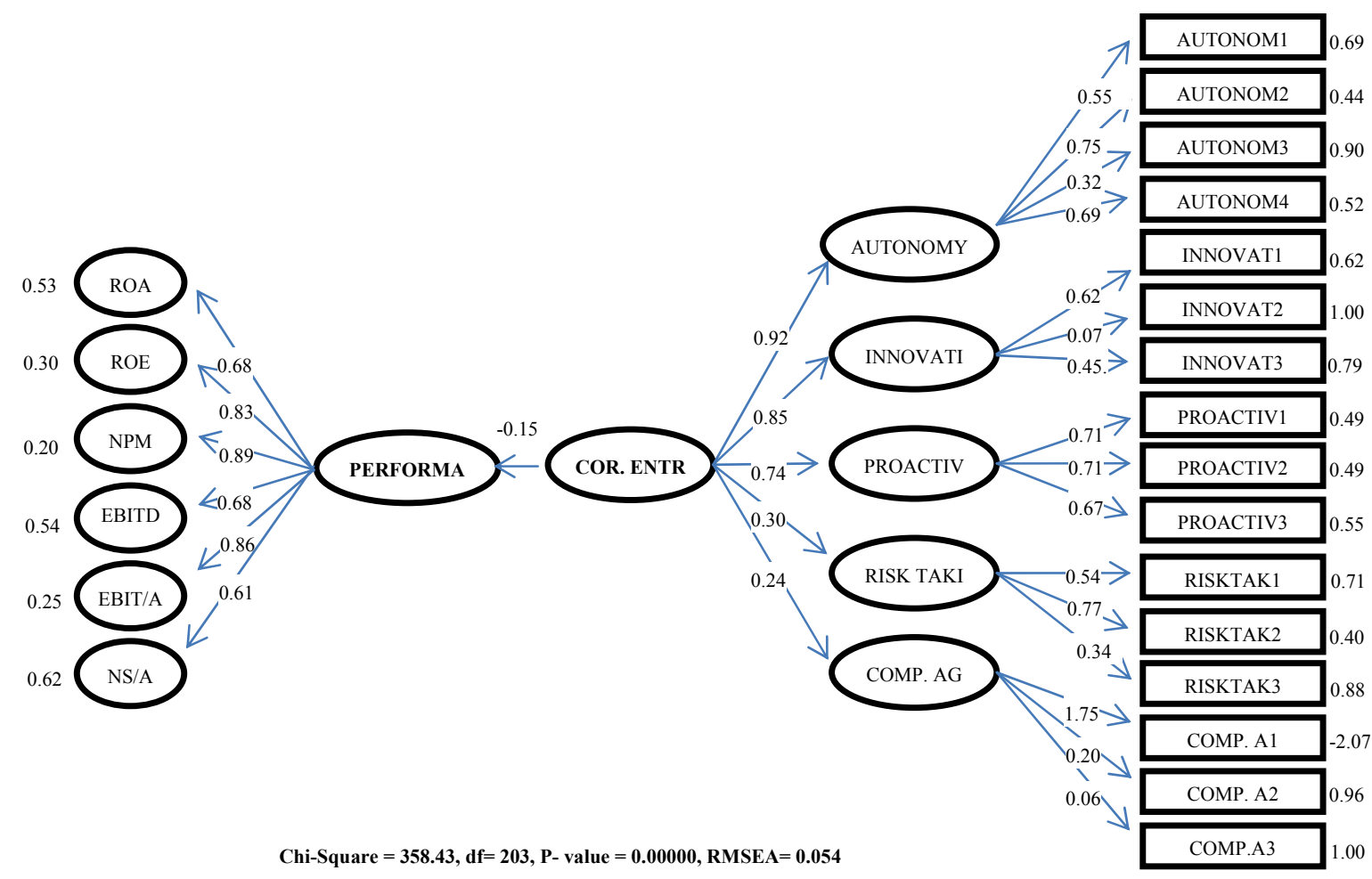

Figure 3. The Effect of Corporate Entrepreneurship on Firm's Performance (Five-Dimensional Model)

According to this, $t$ values of all parameters are meaningful at 0.05 level and statistics for goodness of fit of the model were determined as in Table 3. When the goodness of fit statistics of the model is considered, it can be said that they are good and at an acceptable value ranges. However, the value that demonstrates the impact of corporate entrepreneurship on company performance was negative (-0.15). In other words, it has been concluded that there was a negative interaction between corporate entrepreneurship and financial performance. This result did not meet the positive interaction expectations of this research and the literature. In other words, it was found that while there is an increase in corporate entrepreneurship activities, a decrease exists in firm's performance.

Table 3. Goodness of Fit Statistics of Five-Dimensional Model

\begin{tabular}{lll}
\hline Goodness of Fit Index & Measurement Model Value & Goodness of Fit \\
\hline $\mathrm{X}^{2} / \mathrm{df}$ & $\mathrm{X}^{2} / \mathrm{df}=358.43 / 203=\mathbf{1 . 7 6}$ & Good fit \\
$\mathrm{GFI}$ & $\mathrm{GFI}=\mathbf{0 . 9 4}$ & Acceptable \\
$\mathrm{AGFI}$ & $\mathrm{AGFI}=\mathbf{0 . 9 5}$ & Good fit \\
$\mathrm{CFI}$ & $\mathrm{CFI}=\mathbf{0 . 9 7}$ & Good fit \\
RMSEA & $\mathrm{RMSEA}=\mathbf{0 . 0 5 4}$ & Acceptable \\
$\mathrm{NFI}$ & $\mathrm{NFI}=\mathbf{0 . 9 4}$ & Acceptable \\
\hline
\end{tabular}

Second model that was tested in this research is three dimensional original models which had been developed by Covin and Slevin (1986). This model is statistically significant and has high goodness of fit statistics as shown in Figure 4.

$\mathrm{T}$ values were significant at the level of 0.05 for all parameters in the model. According to the findings, corporate entrepreneurship explains firm performance at the level of 0.74 which is high enough, and there is a positive interaction between them as emphasized in the literature and research hypotheses. 


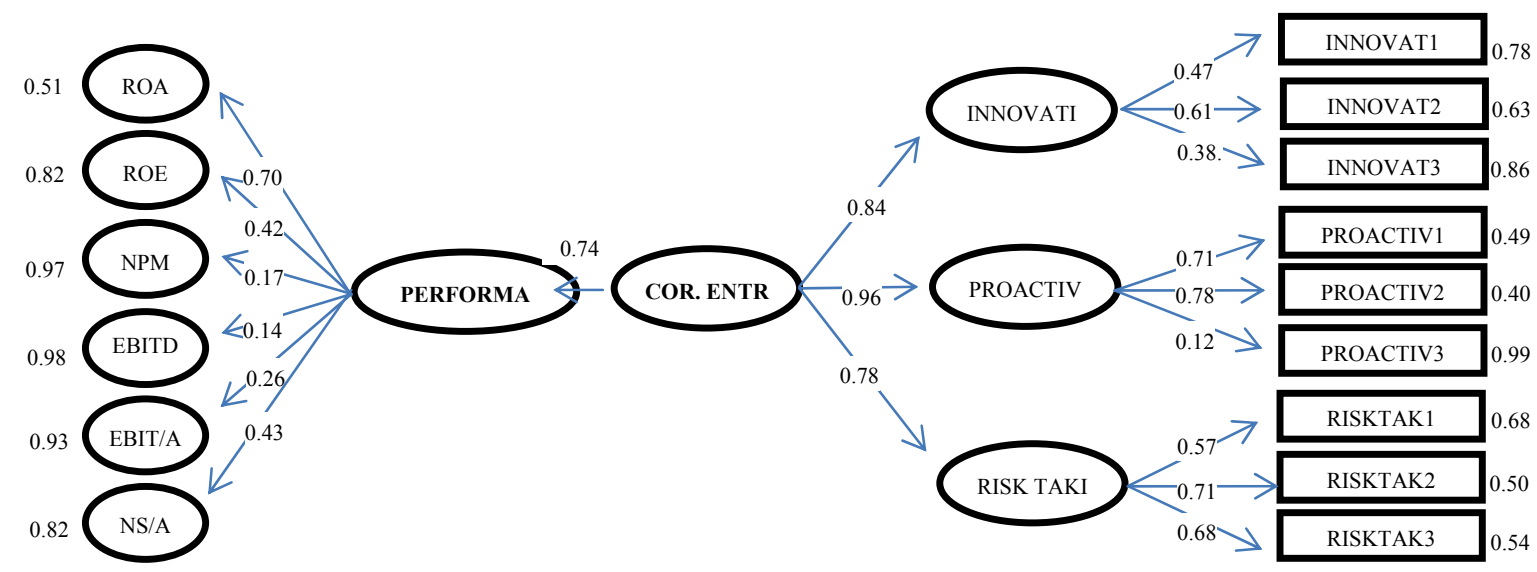

Chi-Square $=156.68, \mathrm{df}=86, \mathrm{P}-$ value $=0.00000, \mathrm{RMSEA}=0.039$

Figure 4. The Effect of Corporate Entrepreneurship on Firm's Performance (Three-Dimensional Model)

As can be seen in Figure 4, proactiveness dimension of corporate entrepreneurship was found to have a very strong impact on the performance of the firm with the value of 0.96 . Dimension of innovation is the second strong effect on the performance with the value of 0.84 and risk taking dimension is the third strong effect on the performance with the value of 0.78 . When we look at the effect of corporate entrepreneurship on performance variables, first ROA (Return on Assets) comes with the value of 0.70, and then NSA (Net Sales/ Assets) comes with the value of 0.43 and last ROE (Return on equity) comes with the value of 0.42 . Good of fitness statistics for the model are generally good and at acceptable value ranges as shown in Table 4.

Table 4. Goodness of Fit Statistics of Three-Dimensional Original Model

\begin{tabular}{lll}
\hline Goodness of Fit Index & Measurement Model Value & Goodness of Fit \\
\hline $\mathrm{X}^{2} / \mathrm{df}$ & $\mathrm{X}^{2} / \mathrm{df}=156.60 / 86=\mathbf{1 . 8 2}$ & Good fit \\
GFI & $\mathrm{GFI}=\mathbf{0 . 9 6}$ & Good fit \\
AGFI & $\mathrm{AGFI}=\mathbf{0 . 9 4}$ & Acceptable \\
CFI & $\mathrm{CFI}=\mathbf{0 . 9 5}$ & Good fit \\
RMSEA & $\mathrm{RMSEA}=\mathbf{0 . 0 3 9}$ & Good fit \\
NFI & $\mathrm{NFI}=\mathbf{0 . 9 4}$ & Acceptable \\
\hline
\end{tabular}

According to the results of two tested models; innovation, proactiveness and risk taking dimensions of corporate entrepreneurship have positive effect on firm performance, so respectively $\mathrm{H}_{2}, \mathrm{H}_{3}$ and $\mathrm{H}_{4}$ hypotheses are supported. On the other hand $\mathrm{H}_{1}$ and $\mathrm{H}_{5}$ hypotheses are rejected as they were about autonomy and competitive aggressiveness dimensions of corporate entrepreneurship. These results are partially consistent with the results of research conducted by Danışman and Erkocaoğlan (2007). Because, in the mentioned study, innovation dimension of corporate entrepreneurship has a positive interaction with profitability as it is in this study. According to research done by Aktan and Bulut (2008), dimensions of corporate entrepreneurship which are innovation, risk taking, proactiveness and competitive aggressiveness have a weak interaction with firms performance. This is also valid for our study with the exception of competitive aggressiveness. According to results of the research done by Alpkan et al. (2005), proactiveness dimension of corporate entrepreneurship has a positive but weak relationship with quantitative financial performance as also indicated in our study. The findings of this research that show a positive relationship between corporate entrepreneurship and firm performance verifies the studies done by Kaya (2006) and Fiş and Çetindamar (2009). And also findings of this research are coherent with the findings of Naman and Slevin (1993); Zahra (1991), (1993); Zahra and Covin (1995). These studies concluded that corporate entrepreneurship has an effect on development of firm performance.

\section{Conclusion}

Corporate entrepreneurship can lead to many positive results in an organizational level and it is a concept studied by many researchers in recent years. Corporate entrepreneurship with its different dimensions was studied and associated with operating performance in the literature. In this study, corporate entrepreneurships' effects on the 
performance of 140 publicly traded companies quoted on the ISE have been indicated with an empirical research.

In the study, the models which were tested had all been developed according to related literature. After testing the developed models with the structural equation modeling with LISREL program; it was found that the five-dimensional model, which consists of innovation, proactiveness, risk taking, autonomy and competitive aggressiveness dimensions (the last two were added later), doesn't have the expected positive effect on performance. It was also seen that although the model had acceptable goodness of fit statistics, it was poor in explaining the relationship or interaction between the variables. Alternative model developed in this study, is called as original model in the literature. According to the results of analysis of this model, corporate entrepreneurship has a strong explanatory power of firm performance as predicted. The goodness of fit statistics of this model is also very good and at the expected level. For this reason, the model that includes the original dimensions of corporate entrepreneurship, which are proactiveness, innovation and risk-taking, was accepted. These three dimensions were found to interact mostly with Return on Assets, Return on equity, Net Sales/ Assets.

In the following studies the relationship between corporate entrepreneurship and firm performance can be handled in the context of qualitative performance measures. Also, the findings of studies on different and larger samples may contribute to the enrichment of the literature.

\section{References}

Aktan, B., \& Bulut, Ç. (2008). Financial performance impacts of corporate entrepreneurship in emerging markets: a case of Turkey. European Journal of Economics, Finance and Administrative Sciences, 12, 69-79.

Alpkan, L., Ergün, E., Bulut, Ç., \& Y1lmaz, C. (2005). Effects of corporate entrepreneurship on firm performance. Doğuş University Journal, 6(2), 175-189.

Altuntaş, G., \& Dönmez, D. (2010). The relationship between entrepreneurial orientation and organizational performance: Evidence from the hotel industry in Çanakkale Region. Istanbul University Journal of the School of Business Administration, 39(1), 50-74.

Antoncic, B., \& Hisrich, R. D. (2004). Corporate entrepreneurship contingencies and organizational wealth creation. Journal of Management Development, 23(6), 518-550. http://dx.doi.org/10.1108/02621710410541114

Barringer, B. R., \& Bluedorn, A. C. (1999) The relationship between corporate entrepreneurship and strategic $\begin{array}{lllll}\text { management. } & \text { Strategic } & \text { Management } & \text { Journal, } & \text { 20, }\end{array}$ http://dx.doi.org/10.1002/(SICI)1097-0266(199905)20:5<421::AID-SMJ30>3.0.CO;2-O

Brewerton, P., \& Milliward, L. (2001). Organizational research methods. Sage Publication.

Brush, C. G., \& Vanderwerf, P. A. (1992). A Comparison of methods and sources for obtaining estimates of new venture performance. Journal of Business Venturing, 17(2), 157-170. http://dx.doi.org/10.1016/0883-9026(92)90010-O

Bulut, C., \& Yilmaz, C. (2008). Innovative performance impacts of corporate entrepreneurship: an empirical research in Turkey. Proceedings of Academy of Innovation and Entrepreneurship Conference, Beijing, China, pp. 414-417.

Covin, J. G., \& Covin, T. J. (1990). Competitive aggressiveness, environmental context and small firm performance. Entrepreneurship Theory and Practice, 14(4), 35-50.

Covin, J. G., \& Slevin, D. P. (1986). The development and testing of an organization-level entrepreneurship scale. In R., Ronstadt, J. A. Hornaday \& K. H. Vesper (Eds.), Frontiers of Entrepreneurship Research (pp. 628-639). Wellesley, MA: Babson College.

Covin, J. G., \& Slevin, D. P. (1989). Strategic management of small firms in hostile and benign environments. Strategic Management Journal, 10, 75-87. http://dx.doi.org/10.1002/smj.4250100107

Danişman, A., \& Erkocaoğlan, E. (2007). Corporate entrepreneurship and firm performance: a research study on İstanbul stock exchange firms. Iktisat İsletme ve Finans, 22(260), 80-101.

Dess, G. G., \& Lumpkin, G. T. (2005). The role of entrepreneurial orientation in stimulating effective corporate entrepreneurship. Academy of Management Executive, 19(1), 147-156.

Dess, G. G., Ireland, R. D., Zahra, S. A., Floyd, S. W., Janney, J. J., \& Lane, P. J. (2003). Emerging issues in corporate entrepreneurship. Journal of Management, 29(3), 351-378. 
Fiş, A. M., \& Çetindamar, D. (2009). The missing link between firm-level entrepreneurship and performance. 9th International Entrepreneurship Forum, İstanbul, 1-12.

Greenley, G. E., \& Foxal, G. R. (1998). External moderation of associations among stakeholder orientation and company performance. International Journal of Research in Marketing, 15(1), 51-69. http://dx.doi.org/10.1016/S0167-8116(97)00018-9

Haber, S., \& Reichel, A. (2005). Identifying performance measures of small ventures-the case of the tourism industry. Journal of Small Business Management, 43(3), 257-286. http://dx.doi.org/10.1111/j.1540-627X.2005.00137.x

Hair, J. F., William, C. B., Barry, J. B., Rolph, E. A., \& Ronald, L. T. (2006). Multivariate data analysis (6th ed.). New Jersay: Pearson/Prentice Hall.

Jöreskog, K. G., \& Dag, S. (1993). LISREL 8: strucrural equation modeling with the simplis command language. SSI Scientific Software International, USA.

Kaya, N. (2006). The impact of human resource management practices and corporate entrepreneurship on firm performance: evidence from Turkish firms. International Journal of Human Resource Management, 17(12), 2074-2900. http://dx.doi.org/10.1080/09585190601000204

Kraus, S., \& Kauranen, I. (2009). Strategic management and entrepreneurship: friends or foes? International Journal of Business Science and Applied Management, 4(1), 37-50.

Lumpkin, G. T., \& Dess, G. G. (1996). Clarifying the entrepreneurial orientation construct and linking it to performance. Academy of Management Review, 21(1), 135-172.

Lumpkin, G. T., \& Dess, G. G. (2001). Linking two dimensions of entrepreneurial orientation to firm performance: the moderating role of environment and industry life cycle. Journal of Business Venturing, 16, 429-451. http://dx.doi.org/10.1016/S0883-9026(00)00048-3

Lumpkin, G. T., Cogliser, C. C., \& Schneider, D. R. (2009). Understanding and measuring autonomy: an entrepreneurial orientation perspective. Entrepreneurship Theory and Practice, 33(1), 47-69. http://dx.doi.org/10.1111/j.1540-6520.2008.00280.x

Miller, D. (1983). The correlates of entrepreneurship in three types of firms. Management Science, 29(7), 770-791. http://dx.doi.org/10.1287/mnsc.29.7.770

Miller, D., \& Friesen, P. H. (1978). Archetypes of strategy formulation. Management Science, 24(9), 921-933. http://dx.doi.org/10.1287/mnsc.24.9.921

Murphy, G. B., Traller, J. W., \& Hill, R. C. (1996). Measuring performance in entrepreneurship. Journal of Business Research, 36(1), 15-23. http://dx.doi.org/10.1016/0148-2963(95)00159-X

Naman, J. L., \& Slevin, D. P. (1993). Entrepreneurship and the concept of fit: a model and empirical tests. Strategic Management Journal, 14, 137-153. http://dx.doi.org/10.1002/smj.4250140205

Nunnally, J. C. (1978). Psychometric Theory (2nd ed.). New York: McGraw-Hill.

Osgood, C. E., Suci, G. C., \& Tannenbaum, P. H. (1957). The Measurement Of Meaning. Illinois Press.

Phillip, H. P., Wright, M., Ucbasaran, D., \& Tan, W. L. (2009). Corporate entrepreneurship: current research and future directions. Journal of business Venturing, 24, 197-205. http://dx.doi.org/10.1016/j.jbusvent.2009.01.007

Pichot, G. III. (1985). Intrapreneuring. New York, NY: Harper \& Row.

Rajshekhar, G. J., Todd, P. R., Johnston, W. J., \& Granot, E. (2012). Entrepreneurship, muddling through, and indian internet-neabled SMEs. Journal of Business Research, 65, 740-744. http://dx.doi.org/10.1016/j.jbusres.2010.12.010

Rauch, A., Wiklund, J., Lumpkin, G. T., \& Frese, M. (2009). Entrepreneurial orientation and business performance: an assessment of past research and suggestions for the future. Entrepreneurship Theory and Practice, 761-787. http://dx.doi.org/10.1111/j.1540-6520.2009.00308.x

Russell, R. D., \& Russell, C. J. (1992). An examination of effects of organizational norms, organizational structure, and environmental uncertainty on entrepreneurial strategy. Journal of Management, 18(4), 639-656. http://dx.doi.org/10.1177/014920639201800403

Sharma, P., \& Chrisman, J. J. (1999). Towards a reconciliation of the definitional issues in the field of corporate 
entrepreneurship. Entrepreneurship Theory and Practice, 23, 11-27

Simsek, Z., Lubatkin, M. H., Veiga, J. F., \& Dino, R. N. (2009). The role of an entrepreneurially alert information system in promoting corporate entrepreneurship. Journal of business research, 62, 810-817. http://dx.doi.org/10.1016/j.jbusres.2008.03.002

Smart, D. T., \& Conant, J. S. (1994). Entrepreneurial orientation, distinctive marketing competencies and organizational performance. Journal of Applied Business Research, 10(3), 28-38.

Wiklund, J. (1999). The sustainability of the entrepreneurial orientation-performance relationship. Entreeneurship Theory and Practice, 23, 37-48.

Wiklund, J., \& Shepherd, D. (2005). Entrepreneurial orientation and small business performance: a configurational approach. Journal of Business Venturing, 20(1), 71-89. http://dx.doi.org/10.1016/j.jbusvent.2004.01.001

Yang, Z., Li-Hua, R., Zhang, X., \& Wang, Y. (2007). Corporate entrepreneurship and market performance: an empirical study in china. Journal of Technology Management in China, 2(2), 154-162. http://dx.doi.org/10.1108/17468770710756086

Yilmaz, V. (2004). Consumer behaviour in shopping center choice. Social Behavior and Personality, 32(8), 783-790. http://dx.doi.org/10.2224/sbp.2004.32.8.783

Zahra, S. A. (1991). Predictors and financial outcomes of corporate entrepreneurship: an exploratory study. Journal of Business Venturing, 6(4), 259-85. http://dx.doi.org/10.1016/0883-9026(91)90019-A

Zahra, S. A. (1993). Environment, corporate entrepreneurship, and financial performance: a taxonomic approach. Journal of Business Venturing, 8(4), 319-340. http://dx.doi.org/10.1016/0883-9026(93)90003-N

Zahra, S. A., \& Covin, J. G. (1995). Contextual influences on the corporate entrepreneurship-performance relationship: a longitudinal analysis. Journal of Business Venturing, 10(1), 43-58. http://dx.doi.org/10.1016/0883-9026(94)00004-E 